\title{
The Discussion on Strengthening the Financial Administration of Enterprises' Fixed Asset under the New Accounting Standard
}

\author{
Longxin $\mathrm{Wu}$ \\ Management College \\ Wuhan Technology and Business University \\ Wuhan, China
}

\begin{abstract}
During the course of enterprise management, the importance of fixed asset is evident and irreplaceable for the daily running activities of enterprises. With the implementation of the New Accounting Standard, the shortcomings of financial management can be seen directed at the enterprises' fixed assets. Therefore, much concrete analysis must be put first on the main problems existing in the management of enterprises' fixed assets, and then some exploration has been made into the influence of the New Accounting Standard upon the management of enterprises' fixed asset. Some strategies have been proposed to strengthen the financial management of enterprises' fixed assets.
\end{abstract}

Keywords-New Accounting Standard; fixed assets; financial management; problems; strategies

\section{INTRODUCTION}

With the implementation of New Accounting Standard, some more strict rules have been proposed for the management of enterprises' fixed assets, which will be directly involved into the more aspects of the running of enterprises and the participation of all members of enterprises. The effective management of enterprises' fixed assets can not only deal with the phenomenon of ambiguous property rights confronted by enterprises, but also can evade the large-scale loss of enterprise assets because of the fault of assets management. The implementation of New Accounting Standard will bring extremely important influences on the financial management of enterprises' fixed assets. It is necessary to do some relevant research into the financial management of enterprises' fixed assets under the New Accounting Standard to ensure the long and stable development of enterprises.

\section{The MAIN PROBLEMS EXISTING IN THE} MANAGEMENT OF ENTERPRISES' FIXED ASSETS

The management of fixed assets is very complicated. The problems with it will bring a lot of bad results. The main problems are as follows:

\section{A. The Unreasonable Organization Structure of the Management of Fixed Assets}

Nowadays, in many enterprises, no special organization or people are responsible for the management of fixed assets. The damage, loss and transfer of the capital cannot be managed timely and therefore the enterprises' fixed assets are ambiguous.

\section{B. The Loss of Enterprises' Fixed Assets Because of the Fault of Investment Underwriting}

This is because of the deficiency of enterprises in legal market awareness and scientific decision-making. Those enterprises are blind in their investment. The behaviors such as illegal guarantee and borrowing and loaning without reference will appear.

\section{The Management Mess of Fixes Assets}

Part of enterprises do not set up the fixed account and ledger card; classification of accounts are not carried out for the management of fixed assets. The present account cannot reflect the number of the assets, the names and the change of money

\section{The Untimely Repairing and Maintaining of Fixed Assets}

To reduce the cost as much as possible, many enterprises do not repair the fixed assets if they can be used. Moreover, some machines in some enterprises are not properly placed.

\section{THE INFLUENCE OF NEW ACCOUNTING STANDARD} UPON THE MANAGEMENT OF ENTERPRISES' FIXED ASSETS

- Compared with the old accounting standard, New Accounting Standard will give the choices of majors to the enterprises, but not only highlight the unit value of fixed assets. In this way, enterprises can give full play to the dynamic role of assets management according to the self-rule and the actual status of enterprises. 
- The term "group assets" has been first proposed in the new accounting standards.After referring to the estimated abandonment costs, the concept of fair value is introduced into the initial dose of fixed assets, and at the same time, the confirmation principle of the follow-up payment of the fixed assets is adjusted rationally. This on one hand can achieve certain controlling effect on human adjustment of profits to a certain extent, but also can more accurately determine the impairment in a forest, and improve the operability of the return value.

- In the new guidelines it is not clearly allowed that impairment reversal can be taken operation, thus this can not only improve the reliability of accounting statements and the great possibility of authenticity, but it also can promote the enterprise management to reduce the profit with assets impairment rushed back.

\section{The Concrete Measures OF Strengthening the} FINANCIAL MANAGEMENT OF ENTERPRISES' FIXED ASSETS

\section{A. Strengthening the Acquisition and Checking Acquisition}

Generally, fixed assets shall be purchased through a written purchase report made to the application department of assets. After the relevant approval procedures, the equipment can be purchased by comparing the quality and price to select the appropriate suppliers; for the purchase of major fixed assets, enterprises still need to select suppliers by way of bidding; compared with other sources of fixed assets, self built fixed assets tend to have more control of the capital expenditure budget.

\section{B. Strengthening the Accounting and Insurance Management of Fixed Assets}

According to the enterprise fixed assets accounting, the enterprises include the clear value of the assets, the clear depreciation method, estimating residual life, asset value, profit and loss of assets disposal, asset impairment calculation and advance etc. The financial department of enterprises needs to weigh up the concrete situation to check the fixed assets on the basis of the national accounting system.

\section{Strengthening the Repairing and Checking Management of Fixed Assets}

The application department of enterprises' fixed assets need to repair and maintain the fixed assets every other time. According to the concrete situation of enterprises themselves, the repair of fixed assets can be divided into the small-scale individual repair and large-scale overall repair. The largescale overall repair can be made after the evaluation work made by the financial department, the management department of fixed assets and assets application department and the repairing plan made on the basis of the rules. The small-scale individual repair must obey the relevant rule and the cost can be paid by the financial department.

\section{Strengthening the Handling and Transferring of Fixed Assets}

The enterprises should adopt the correspondent managing strategies according to the differences of handling the fixed assets. The handling of the fixed assets should be made by other independent departments and their clerks other than the management department and the application department of fixed assets. For the handling and transferring of the important fixed assets, the enterprises will entrust third party intermediary to evaluate the value of the assets and make the detailed recording of the process and results of getting examined and approved. In this way, the safe handling and transferring of fixed assets of enterprises can be made.

\section{CONCLUSION}

All in all, the implementation of new accounting standard directly lead to the new tests and challenges confronted by enterprises in the confirmation, the entry value and the discounts of fixed assets. In order to maintain the long and stable development, the enterprises must strengthen the accepting and checking, insuring and repairing, handling and transferring of fixed assets, to realize the high effectiveness and scientification of financial management of enterprises' fixed assets.

\section{REFERENCES}

[1] Jiao Jiali. The Thoughts on Strengthening the Management of Enterprises' Subsequent Expenditure[J]. Friends of Accountants. 2013,(15).

[2] Liu Xiuqin, Chen Linhua. The Application of EXCEL in the Financial Management of Fixed Assets[J]. Business Accountants. 2014, (15)

[3] Ding Guoli. The Financial Management Path of Reducing the Investment Cost of Fixed Assets[J]. Enterprises Reforming and Managing. 2016, (18).

[4] Wang Guoxia. Problems and Strategies of Financial Management of Enterprises' Fixed Assets[J]. Chinese and Foreign Entrepreneur. 2015, (12). 